\title{
Evaluation of hygienic-sanitary conditions of hospital nutrition and dietary services from the perspectives of internal and external auditors
} Lize STANGARLIN ${ }^{1}$, Luisa Helena HECKTHEUER ${ }^{1}$, Ana Lucia SERAFIM ${ }^{1}$, Laissa Benites MEDEIROS ${ }^{1 *}$

\begin{abstract}
The objective of this study was to evaluate the hygienic-sanitary conditions of hospital nutrition and dietary services using external and internal auditors. Eleven hospitals were evaluated for their nutrition and dietary services using an evaluation checklist based on food safety requirements in the current legislation. The checklist was applied by an internal auditor (a technical supervisor) and an external auditor (a professional with experience in food services) between August and October 2011. According to the number of items on the evaluation checklist that were considered adequate, the hospital facilities were ranked as excellent, good, regular, bad, or very bad. The results obtained by the auditors were compared. According to these results, it can be said that most of the hospital nutrition and dietary services were rated as good for overall quality by the internal auditor, while the external auditor classified them as Regular. There was a clear difference between the evaluations of the auditors, both in terms of the number of items considered adequate and the overall requirements' average score. It can be concluded that hospital nutrition and dietary services should meet safety requirements in order to provide food. These facilities should have external audits conducted as a way to prevent routine problems from being perpetuated.
\end{abstract}

Keywords: food handling; good manipulation practices; food safety.

\section{Introduction}

In hospitals, nutrition and dietary services should be part of a structured and organized department that provides nutritional assistance by preparing high-quality meals with high standards of food safety. Minimizing risks is essential to protect patients from possible foodborne diseases (SETA et al., 2010; NEWELL et al., 2010; TODD et al., 2007; STANGARLIN et al., 2013).

In the hospital environment, the risk of contracting foodborne diseases is great because the food is meant to employees, caregivers, and patients, whose immune systems may be weakened (SILVA NETO, 2006; RÉGLIER-POUPET et al., 2005; RODRIGUEZ et al., 2011). Foodborne diseases can aggravate the health state of the patients and generate unnecessary medical spending, affecting the operation of hospital services (LUND; O’BRIEN, 2009).

According to Tokuc et al. (2009), the mishandling of food facilitates the spread of pathogens that cause foodborne disease outbreaks in hospitals, which affects employees, visitors, and patients, especially those with low immunity. Offering a safe meal for these individuals is very important, and a systematic approach is required to control food contaminants. This approach includes implementing tools to preserve the hygienicsanitary quality of foods, updating knowledge and perceptions, and supervising the technical staff members responsible for identifying factors that may contribute to the development of the foodborne diseases (BUCCHERI et al., 2007; SEAMAN; EVES, 2008; SOUSA; CAMPOS, 2003).
Among the tools used by food companies to promote hygienic-sanitary quality is the Good Practices program. This program, which is regulated by current laws to assist in the production and commercialization of food, is the main legal mechanism to protect the health of individuals (SANTANA et al., 2009; SACCO; ORTIGOZA, 2007).

Currently, in Brazil, there is no legislation on implementing tools to promote hygienic and sanitary quality of food in hospital nutrition and dietary services. The existing technical regulations do not include the surveillance of these facilities, but they are used as a reference in this segment because they help the control of food safety (STANGARLIN et al., 2013). Thus, the hospital staff members responsible for it may have difficulty implementing the procedures that are required to control the quality and safety of food (STANGARLIN, 2008).

Therefore, this study aimed to evaluate the hygienicsanitary conditions in hospital nutrition and dietary services and compare the evaluation performed by internal and external auditors.

\section{Materials and methods}

To determine the sample for this study, a survey of all the hospitals that belong to the 4th Regional Coordination of Health of RS in Brazil was conducted through the Secretary of Health of the city of Santa Maria, Rio Grande do Sul (RS). There are 26 hospitals located in the following cities: Agudo, Cacequi, Dona Francisca, Faxinal do Soturno, Formigueiro, Ivorá, Jaguari, Júlio de Castilhos, Mata, Nova Palma, Paraíso do Sul, Pinhal Grande,

\footnotetext{
Received 25/2/2013

Accepted 11/5/2013

${ }_{1}$ Program in Food Science and Technology, Federal University of Santa Maria - UFSM, Rua Appel, 132, apto 04, Bom Fim, CEP 97015-030, Santa Maria, RS, Brasil, e-mail:laissa_medeiros_1@hotmail.com

${ }^{*}$ Corresponding author
}

DOI: http://dx.doi.org/10.1590/S0101-20612013005000058 
Restinga Seca, Santa Maria, Santiago, São Francisco de Assis, São Pedro do Sul, São Sepé, São Vicente do Sul, and Silveira Martins.

The inclusion criterion was the participation of at least one staff member responsible for the hospital nutrition and dietary services.

In this study, each of the hospital nutrition and dietary services was evaluated by the responsible staff member, who was considered the internal auditor. A external auditor, a professional with experience in the food area, also evaluated all the locations. The auditors' evaluations of the nutrition and dietary services were conducted in every hospital between August and October 2011 with no consultation between the auditors.

All of the areas involved in the hospital nutrition and dietary service (i.e., the receiving area, areas where food was stored and prepared, areas where utensils were cleaned, the kitchens, the locker rooms, and the restrooms used by the food handlers) were considered for the evaluation in the present study. The lactary and enteral nutrition services were not considered because they have their own specific regulations.

As a data collection tool to evaluate the hospital nutrition and dietary services using the criteria required to ensure food safety, an evaluation checklist was prepared during the months of June and July 2011. This list, elaborated by Stangarlin et al. (2013), included the requirements under the current legislation and regulatory standards in Brazil, including Ordinance No. 326/1997 (BRASIL, 1997), Resolution Board (RDC) No 275/2002 (BRASIL, 2002); Ordinance No. 78/2009 (RIO GRANDE DO SUL, 2009); CVS Ordinance No. 6/1999 (SÃO PAULO, 1999), and the guidelines of the Brazilian Association of Technical Standards - ABNT NBR 15635:2008 (ASSOCIAÇÃO..., 2008).

The evaluation checklist comprised the following checkpoints: buildings and physical facilities (type of building material and the condition of facilities); equipment, furniture, and utensils (material type, condition and operation); maintenance and equipment calibration (procedures and records regarding the maintenance of equipment and records of the calibration of the measuring instruments); hygiene of the facilities, equipment, furniture and utensils (procedures, sanitizing products and utensils used for cleaning); water supply (drinkability, responsible staff members, and records of the frequency of water reservoir cleaning); integrated control of urban vector and pest (preventive and chemical control); waste management (collectors and collection procedures); food handlers (health, personal hygiene, behavior, uniforms, and training records); operational steps (working with suppliers, receiving food, storing food, handling food, defrosting, washing fruits and vegetables, using eggs, conducting heat treatment, cooling, evaluating food using time and temperature criteria, maintaining and distributing ready-to-eat food, and storing samples); and documentation (implementation of Good Handling Practices, Standard Operating Procedures and Essential Operational Controls).

In the list of requirements, each item was evaluated as not applicable (when the question did not include activities conducted in the hospital nutrition and dietary service), appropriate or inappropriate. The number of items that met the requirements were counted upon; the hospital facilities with a percentage between 91-100\% were classified as excellent, 70$90 \%$ were classified as good, 50-69\% were classified as Regular, 20-49\% were classified as bad, and 0-19\% were classified as very bad (STANGARLIN et al., 2013).

After the internal and external auditors had completed the evaluation of each of the hospital nutrition and dietary services, the percentage of overall adequacy and the requirements was compared. The results were evaluated using the Statistical Package for the Social Sciences (SPSS) software version 19.0. The data were analyzed using simple descriptive statistics (mean \pm standard deviation, median, percentile, and percentage). To compare the overall quality averages and the requirement scores given by auditors, the $\mathrm{T}$ test for paired samples were used. The threshold for statistically significant differences between groups was set at $\mathrm{p}<0.05$.

This study was conducted in accordance with the ethical standards in Resolution No. 196/96 (BRASIL, 1996) with the approval of the Research Ethics Committee under number 08120512.6.0000.5346.

\section{Results and discussion}

After applying the inclusion criteria, the sample used in the present study consisted of 11 hospital nutrition and dietary services. Among the potentially eligible hospital subjects for this research, 7 had no staff members responsible for these services, and 8 did not agree to participate in the study. Costa and Rocha (2010) state that the responsible staff member should have specific knowledge about hospital nutrition and dietary services and should play a role in the preservation, promotion, and restoration of the patients' health, which are standards established by the current legislation (CONSELHO..., 2005; BRASIL, 1991).

Table 1 shows the overall hospital quality classifications according to their nutrition and dietary services after the internal and external auditions. It is possible verify that the internal auditors classified 2 of the hospital services as excellent,

Table 1. Classification of the overall hygienic-sanitary quality of the nutrition and dietary services evaluated by internal and external auditors in hospitals in the 4th Regional Coordination of Health (RS), Brazil, 2011.

\begin{tabular}{|c|c|c|}
\hline \multirow{2}{*}{$\begin{array}{l}\text { Hospital nutrition and } \\
\text { dietary service }\end{array}$} & Internal auditor & External auditor \\
\hline & Classification & Classification \\
\hline 1 & Good & Regular \\
\hline 2 & Good & $\mathrm{Bad}$ \\
\hline 3 & Regular & $\mathrm{Bad}$ \\
\hline 4 & Good & Regular \\
\hline 5 & Excellent & Regular \\
\hline 6 & Good & Regular \\
\hline 7 & Regular & Regular \\
\hline 8 & Excellent & $\mathrm{Bad}$ \\
\hline 9 & Good & Regular \\
\hline 10 & Good & Good \\
\hline 11 & Good & Good \\
\hline
\end{tabular}


whereas the external auditor classified these services as regular and bad. It was also found that the internal auditor classified 7 of the hospital services as good, while the external auditor classified only 2 of these services the same way and the others as regular and bad.

The results obtained showed the difference between the two evaluators, a result that demonstrates the importance of an external view to identify nonconformities that cannot be perceived with regular work routines.

Given these classifications, it is suggested that some hospitals review the minimum requirements for food safety due to the importance of providing safe and high-quality meals in a hospital environment. A study on hospital nutrition and dietary services conducted in the city of São Miguel do Guamá (PA) also found irregularities in the adherence to the criteria required for food security and classified the facility as unsatisfactory (FARIAS; PEREIRA; FIGUEIREDO, 2011).

Table 2 shows the comparison between the percentage of facilities considered adequate and the overall average scores given by both the internal and external auditors. When the evaluations of the auditors are compared in terms of the overall average of requirements considered adequate, a statistically significant difference $(\mathrm{p}=0.009)$ was found.

The overall average percentage of hospital facilities considered adequate for the requirements on the evaluation list was $74 \%$ according to the evaluations of the the internal auditors, while the average found in the concomitant evaluations by the external auditor was $59 \%$. Based on these data, there is a difference between the evaluations of the auditors; the external auditors were more critical in their evaluations than the internal auditors. This evidence demonstrates the importance of having external individuals perform unbiased reviews in the location of professional performance.

According to Saccol et al. (2009), the differences in the results found in the evaluation of the food safety requirements indicate that those responsible for food services are used to the nonconformities in their workplace. On the other hand, Proença et al. (2005) state that non-compliance with the requirements can be linked to the fact that technical professionals are not aware of the recommended standards due to the absence of pre-established quality criteria or to the fact that staff members are over-stretched.

In the external evaluator's evaluation of the requirements in the list (Table 2), it was found that the highest percentage of compliance was related to the integrated control of urban vector and pest as well as to water supply. Based on this result, it was found that these requirements may exhibit greater compliance because of the standards of the health surveillance agencies in these cities.

According to a study by Santos et al. (2012), who evaluated the performance of two existing laws for implementing quality programs in restaurants in the city of Brasília, it was found that only one of the laws is being enforced because it is more frequently required in the municipal surveillance audits. According to Soto et al. (2009), improving these requirements, which are more accurately evaluated by the Health Surveillance, will be effective and sustainable as long as the periodic inspections scheduled by the Health Surveillance are maintained.

The external auditor found that the documentation requirement (Table 2) had the lowest percentage of compliance in relation to the other items evaluated (i.e., the facilities failed to provide the Manual of Good Handling Practices, Standard Operating Procedures, and Essential Operational Control). The hospital nutrition and dietary services that had these documents used the RDC Resolution No. 216/2004 as reference.

These results indicate ignorance of the existing laws because this resolution does not include to lactaries, units of enteral nutrition therapy, human milk banks, and kitchens of health care facilities and industrial food establishments (BRASIL, 2004). Therefore, this resolution should not be used in hospital nutrition and dietary services.

Table 2. Comparison of the percentage of facilities considered adequate and the overall average of the hospital nutrition and dietary services requirements evaluated by internal and external auditors in the hospitals in the 4th Regional Coordination of Health (RS), Brazil, 2011.

\begin{tabular}{|c|c|c|c|}
\hline \multirow[b]{2}{*}{ Requirements } & \multicolumn{2}{|c|}{ Requirements considered adequate (\%) } & \multirow[b]{2}{*}{$\mathrm{p}^{\star}$} \\
\hline & $\begin{array}{l}\text { Internal auditors } \\
\text { Mean } \pm \text { SD }\end{array}$ & $\begin{array}{l}\text { External auditors } \\
\text { Mean } \pm \text { SD }\end{array}$ & \\
\hline Building and physical facilities & $67 \pm 13$ & $72 \pm 7$ & 0.30 \\
\hline Equipment, furniture, and utensils & $74 \pm 28$ & $69 \pm 25$ & 0.67 \\
\hline Maintenance and equipment calibration & $48 \pm 33$ & $28 \pm 23$ & 0.17 \\
\hline Hygiene of the facilities, equipment, furniture, and utensils & $90 \pm 9$ & $66 \pm 11$ & 0.01 \\
\hline Water supply & $86 \pm 17$ & $90 \pm 19$ & 0.71 \\
\hline Integrated control of urban vector and pest & $98 \pm 6$ & $93 \pm 13$ & 0.17 \\
\hline Waste management & $66 \pm 29$ & $70 \pm 25$ & 0.64 \\
\hline Food handlers & $68 \pm 15$ & $56 \pm 13$ & 0.06 \\
\hline Operational steps & $82 \pm 13$ & $58 \pm 14$ & 0.005 \\
\hline Documentation & $61 \pm 31$ & $9 \pm 18$ & 0.004 \\
\hline Overall average of requirements considered adequate & $74 \pm 9$ & $59 \pm 9$ & 0.009 \\
\hline
\end{tabular}

$\%$ : Percentage; Mean; SD: standard deviation. ${ }^{*} \mathrm{~T}$ test for independent samples. 
Currently, in Brazil, there is no legislation on implementing tools to promote hygienic and sanitary tools for food service in hospital nutrition and dietary services. However, the Brazilian Association of Technical Standards published the NBR Normative 15.635:2008, which includes hospital kitchens. This guideline describes the documents that set the stages of food preparation, namely the Manual of Good Handling Practices, Standard Operating Procedures, and Essential Operational Control (ASSOCIAÇÃO..., 2008).

Keeping records of these practices in these documents is essential because it standardizes the procedures and improves the hygienic-sanitary conditions of food services (RODRIGUES; SILVA; ALEIXO, 2012). A study conducted in an establishment in the city of Rio de Janeiro (RJ) found that after the development and implementation of the documents, the hygienic procedures improved and became more standardized, employees performed more tasks, food waste decreased, and the sanitary inspection location was deeper (FERREIRA NETO; GUIMARÃES; SÁRCIA, 2007). It is also important to note that the use of highquality tools in food services requires not only the existence of documents and standards, but also their effective integration with the company procedures (VEIROS et al., 2009).

After applying the evaluation checklist (Table 2), the external auditor found compliance rates that were significantly lower than the those found by the internal auditors concerning the requirements related to the sanitation of the facilities, equipment, furniture, and utensils $(\mathrm{p}=0.01)$, operational stages $(\mathrm{p}=0.005)$, and documentation $(\mathrm{p}=0.004)$. The requirements that showed the greatest compliance with the requirements in terms of hospital nutrition and dietary services, according to the internal auditors, were those that required their supervision. This result demonstrates that the work routine and the environment can influence perceptions of nonconformities.

According to Seaman and Eves (2010), some food service supervisors have limited awareness or poor food handling and hygiene, which makes it more difficult to evaluate the facilities. Adequate information that is updated in training sessions, identifying factors that contribute to positive attitudes, and changing the behavior of some individuals in these facilities can minimize the contamination of foods (ACIKEL et al., 2008; BUCCHERI et al., 2007).

According to the Codex Alimentarius, food is only considered safe and unadulterated if practices, inspections, and tools are used to ensure the quality of food (FOOD..., 2006). Quick observations and actions to eliminate the cause of detected nonconformities during food preparation, as well as the adoption of preventive and corrective measures, are essential to ensure hygienic-sanitary conditions because any failure during any of the stages of preparation may jeopardize and harm the food that is being prepared (BADARÓ; AZEREDO; ALMEIDA, 2007; OZILGEN, 2012).

\section{Conclusions}

Based on the results obtained in the present study, it is concluded that hospitals' internal auditors classified most of the nutrition and dietary services as having good overall quality, whereas the external auditors classified most services as Regular. There was a statistically significant difference between the evaluations of the auditors.

Therefore, hospital nutrition and dietary services should adequately meet the requirements for food safety. The internal auditors should deepen their knowledge about the quality and safety of food to be able to perform a more thorough and critical analysis and detect possible nonconformities, mainly concerning the requirements that require their supervision.

It is worth mentioning that external audits are important to avoid perpetuating routine problems because they offer an impartial evaluation of the nonconformities found.

\section{References}

ACIKEL, C. H. et al. The hygiene training of food handlers at a teaching hospital. Food Control, v. 19, n. 2, p. 186-190, 2008. http://dx.doi. org/10.1016/j.foodcont.2007.03.008

ASSOCIAÇÃO BRASILEIRA DE NORMAS TÉCNICAS - ABNT. NBR 15.635: Serviços de Alimentação: Requisitos de Boas Práticas higiênico-sanitárias e controles operacionais essenciais. Rio de Janeiro: ABNT; 2008.

BADARÓ, A. C. L.; AZEREDO, R. M. C.; ALMEIDA, M. E. F. Vigilância Sanitária de Alimentos: Uma Revisão. Nutrir Gerais, v. 1, n. 1, p. 1-25, 2007.

BRASIL. Decreto Lei n 8234, de 17 de setembro de 1991. Regulamenta a profissão de Nutricionista e determina outras providências. Diário Oficial da República Federativa do Brasil, Brasília, DF, 19 set. 1991. Seção 1, p. 19909.

BRASIL. Ministério da Saúde. Conselho Nacional de Saúde. Comissão Nacional de Ética em Pesquisa. Resolução CNS nº 196, de 10 de outubro de 1996. Aprova as Diretrizes e Normas Regulamentadoras de Pesquisas envolvendo Seres Humanos. Diário Oficial da República Federativa do Brasil, Brasília, DF, 16 out. 1996. Seção 1, p. 21.082-21.085.

BRASIL. Ministério da Saúde. Agência Nacional de Vigilância Sanitária. Resolução RDC n 216, de 15 de setembro de 2004. Dispõe sobre Regulamento Técnico de Boas Práticas para Serviços de Alimentação. Diário Oficial da República Federativa do Brasil, Brasília, DF, 16 set. 2004. Seção 1, p. 1-10.

BRASIL. Ministério da Saúde. Agência Nacional de Vigilância Sanitária. Resolução RDC no 275, de 21 de outubro de 2002. Dispõe sobre o Regulamento Técnico de Procedimentos Operacionais Padronizados aplicados aos Estabelecimentos Produtores/Industrializadores de Alimentos e a Lista de Verificação das Boas Práticas de Fabricação em Estabelecimentos Produtores/Industrializadores de Alimentos. Diário Oficial da República Federativa do Brasil, Brasília, DF, 06 nov. 2002. Seção 1, p. 4-21.

BRASIL. Ministério da Saúde. Secretaria de Vigilância Sanitária. Portaria SVS nº 326, de 30 de julho de 1997. Regulamento Técnico sobre as Condições Higiênico-Sanitárias e de Boas Práticas de Fabricação para Estabelecimentos Produtores/Industrializadores de Alimentos. Diário Oficial da República Federativa do Brasil, Brasília, DF, 01 ago. 1997. Seção 1, p. 16560-3.

BUCCHERI, C. et al. Food safety in hospital: knowledge, attitudes and practices of nursing staff of two hospitals in Sicily, Italy. Health Services Research, v. 7, n. 45, p. 1-11, 2007.

CONSELHO FEDERAL DE NUTRICIONISTAS. Resolução CFN $n^{\circ}$ 380, de 9 de janeiro de 2005. Dispõe sobre a definição das 
áreas de atuação do nutricionista e suas atribuições, estabelece parâmetros numéricos de referência, por área de atuação, e dá outras providências. Diário Oficial da República Federativa do Brasil, Brasília, DF, 10 jan. 2006. Seção 1.

COSTA, C. S. B. G.; ROCHA, A. Caracterização da qualidade das refeições servidas num centro hospitalar. 2010. 60 f. Dissertação (Mestrado em Ciência da Nutrição)-Faculdade de Ciências da Nutrição e Alimentação da Universidade do Porto, Porto, 2010.

FARIAS, J. K. R.; PEREIRA, M. M. S.; FIGUEIREDO, E. L. Avaliação de boas práticas e contagem microbiológica das refeições de uma unidade de alimentação Hospitalar, do município de são Miguel do Guamá - Pará. Alimentos e Nutrição, v. 22, n. 1, p. 113-119, 2011.

FERREIRA NETO, C. S. F.; GUIMARÃES, K. A. S.; SÁRCIA, W. Implementação dos Procedimentos Operacionais Padronizados numa Unidade de Alimentação e Nutrição Institucional, na cidade do Rio de Janeiro, RJ. Higiene Alimentar, v. 21, n. 154, p. 18 21, 2007.

FOOD AND AGRICULTURE ORGANIZATION - FAO; WORLD HEALTH ORGANIZATION - WHO. Recommended International Code of Practice - General Principles of Food Hygiene. Codex Alimentarius Commission/RCP 1. 4th ed. FAO, 2006.

LUND, B. M.; O'BRIEN, S. J. Microbiological safety of food in hospitals and other healthcare settings. The Journal of Hospital Infection, v. 73, n. 2, p. 109-120, 2009. PMid:19732991. http://dx.doi. org/10.1016/j.jhin.2009.05.017

NEWELL, D. G. et al. Food-borne diseases: the challenges of 20 years ago still persist while new ones continue to emerge. International Journal of Food Microbiology, v. 139, n. 1, p. S3-S15, 2010. PMid:20153070. http://dx.doi.org/10.1016/j. ijfoodmicro.2010.01.021

OZILGEN, S. Failure Mode and Effect Analysis (FMEA) for confectionery manufacturing in developing countries: Turkish delight production as a case study. Ciência e Tecnologia de Alimentos, v. 32, n. 3, p. 505-514, 2012. http://dx.doi.org/10.1590/ S0101-20612012005000083

PROENÇA, R. P. C. et al. Qualidade Nutricional e Sensorial na produção de Refeições. Nutrição em Pauta, v. 13, n. 75, p. 4-16, 2005.

RÉGLIER-POUPET, H. et al. Evaluation of the quality of hospital food from the kitchen to the patient. The Journal of Hospital Infection, v. 59, n. 2, p. 131-137, 2005. PMid:15620447. http:// dx.doi.org/10.1016/j.jhin.2004.07.023

RIO GRANDE DO SUL. Secretaria da Saúde. Portaria no 78, de 30 de janeiro de 2009. Aprova a lista de verificação em Boas Práticas para serviços de alimentação, aprova normas para cursos de capacitação em Boas Práticas para serviços de alimentação e dá outras providências. Diário Oficial do Estado do Rio Grande do Sul, Porto Alegre, 30 jan. 2009. p. 35-40.

RODRIGUES, K. L.; SILVA, J. A.; ALEIXO, J. A. G. Effect of the implementation of the Hazard Analysis Critical Control Point (HACCP) prerequisite program in an institutional foodservice unit in Southern Brazil. Ciência e Tecnologia de Alimentos, v. 32, n. 1, p. 196-200, 2012. http://dx.doi.org/10.1590/S010120612012005000018

RODRIGUEZ, M. et al. Hygienic conditions and microbiological status of chilled Ready-To-Eat products served in Southern Spanish hospitals. Food Control, v. 22, n. 6, p. 874-882, 2011. http://dx.doi. org/10.1016/j.foodcont.2010.11.015

SACCO, G. B.; ORTIGOZA, S. A. G. O papel da educação em saúde como instrumento de melhoria na manipulação/comercialização de alimentos pelos Hamburgueiros de Rio Claro, SP. Higiene Alimentar, v. 21, n. 151, p. 73-78, 2007.
SACCOL, A. L. F. et al. Avaliação das Boas Práticas em duas visões: técnica e da empresa. Brazilian Journal of Food and Technology, p. 19-23, 2009. II SSA.

SANTANA, N. G. et al. Microbiological quality and safety of meals served to children and adoption of good manufacturing practices in public school catering in Brazil. Food Control, v. 20, n. 3, p. 255261, 2009. http://dx.doi.org/10.1016/j.foodcont.2008.05.004

SANTOS, L. L. et al. Food service compliance with ISO 14001 and ISO 22000. Revista de Nutrição, v. 25, n. 3, p. 373-380, 2012. http:// dx.doi.org/10.1590/S1415-52732012000300007

SÃO PAULO. Secretaria do Estado da Saúde. Diretoria Técnica do Centro de Vigilância Sanitária. Portaria CVS no 6, 10 de março de 1999. Estabelece o regulamento técnico sobre os parâmetros e critérios para o controle higiênico-sanitário em estabelecimentos de alimentos. Diário Oficial do Estado de São Paulo, São Paulo, 12 mar. 1999.

SEAMAN, P.; EVES, A. Food hygiene training in small to medium sized care settings. International Journal of Environmental Health Research, v. 18, n. 5, p. 365-374, 2008. PMid:18821375. http://dx.doi. org/10.1080/09603120802272193

SEAMAN, P.; EVES, A. Perceptions of hygiene training amongst food handlers, managers and training providers - A qualitative study. Food Control, v. 21, n. 7, p. 1037-1041, 2010. http://dx.doi. org/10.1016/j.foodcont.2009.12.024

SETA, M. H. et al. Cuidado nutricional em hospitais públicos de quatro estados brasileiros: contribuições da avaliação em saúde à vigilância sanitária de serviços. Ciência e Saúde Coletiva, v. 15, n. 3, p. 3413-3422, 2010. PMid:21120329. http://dx.doi.org/10.1590/ S1413-81232010000900016

SILVA NETO, M. S. Diagnóstico situacional da utilização das ferramentas de segurança na produção de alimentos nas cozinhas das unidades de alimentação e Nutrição dos Hospitais de Brasília-DF. 2006. 122 f. Dissertação (Mestrado em Nutrição Humana)-Universidade Brasília, Brasília, 2006.

SOTO, F. R. M. et al . Aplicação experimental de um modelo de conduta de inspeção sanitária no comércio varejista de alimentos. Ciência e Tecnologia de Alimentos, v. 29, n. 2, p. 371-374, 2009. http:// dx.doi.org/10.1590/S0101-20612009000200021

SOUSA, C. L.; CAMPOS, G. D. Condições higiênico-sanitárias de uma dieta hospitalar. Revista de Nutrição, v. 16, n.1, p. 127-134, 2003. http://dx.doi.org/10.1590/S1415-52732003000100013

STANGARLIN, L. Avaliação das condições de qualidade em Serviços de Alimentação e Unidades Hospitalares na cidade de Santa Maria, RS. 2008. 192 f. Dissertação (Mestre em Ciência e Tecnologia dos Alimentos)-Universidade Federal de Santa Maria, Santa Maria, 2008.

STANGARLIN, L. et al. Instrumentos e Apoio para Implantação das Boas Práticas em Serviços de Nutrição e Dietética Hospitalar. Rio de Janeiro: Rubio, 2013.

TODD, E. C. D. et al. Outbreaks where food workers have been implicated in the spread of foodborne disease. Part 3. Factors contributing to outbreaks and description of outbreak categories. Journal of Food Protection, v. 70, n. 9, p. 2199-217, 2007. Pmid:17900100.

TOKUC, B. et al. Knowledge, attitudes and self-reported practices of food service staff regarding food hygiene in Edirne, Turkey. Food Control, v. 20, n. 6, p. 565-568, 2009. http://dx.doi.org/10.1016/j. foodcont.2008.08.013

VEIROS, M. B. et al. Food safety practices in a Portuguese canteen. Food Control, v. 20, n. 10, p. 936-941, 2009. http://dx.doi. org/10.1016/j.foodcont.2009.02.002 